Vol. 7, No. 1, 2021

Roman Frankiv

\title{
IDEOLOGICAL ASPECTS OF THE ARCHITECTURE OF NATIONAL DETERMINED HISTORICISM ON THE EXAMPLE OF UKRAINIAN, POLISH AND RUSSIAN NARRATIVES
}

\author{
PhD, Associate Professor Department of Architectural Design \\ Lviv Polytechnic National University, Lviv \\ e-mail: romanfrankiv@gmail.com \\ orcid: 0000-0003-1100-0930
}

Received: 03.12.2020 / Revised: 20.04.2021 / Accepted: 03.05.2021

(C) Frankiv R., 2021

https://doi.org/10.23939/as2021.01.024

\begin{abstract}
This article explores the ideological and narrative foundations of various forms of architectural historicism, marked by the identities manifestation which emerged in the era of modern nations appearance. The difference between the concepts of the three national communities - Ukrainian, Polish and Russian and how these concepts were conveyed with the help of architectural stylistics is outlined. It is determined that in all three cases, the main source of style-creation was the idea of the Ideal Homeland, which in all three national narratives accounts for the late Middle Ages (XVI-XVII centuries.) Also is suggested the concept of evaluative delimitation of this kind of heritage, depending on the inherent symbolic ideals.
\end{abstract}

Key words: historicism, nation, modernity, narrative, identity.

\section{Introduction}

Over the past few decades, the concept of "historical heritage" has undergone significant expansion and thematic diversity (Lamprakos M.. 2014), the value of certain objects has been determined not only by their artistic and aesthetic qualities, or historical significance. Gradually, there was an idea that even insignificant elements of the subject environment have value because they carry "evidence of their time" Thus, a situation arose when virtually the entire space of settlements became possible to interpret as a heritage, regardless of its ideological, functional and artistic content. On the one hand, this approach serves for a more respectful attitude to oneself living environment, information intellectualization of residents and diversity of space. However, on the other hand, there is a threat of devaluation of the very concept of value. If all objects that appear in the city automatically become heritage, such categories as artistic value, functional convenience, ideological motivation lose their significance. Therefore, there is a need to formulate new criteria for heritage gradation to avoid nihilistic monotony.

In this case, it is not an issue of proposing to eliminate some objects from the category of "heritage", but to develop its interpretation, so that the messages inserted by creators of such object during their 
design, were more understandable. At the present stage of heritage discourse, the concept of identity is considered to be the most promising platform for such a gradation (Jokilehto J.. 2008).

While in North America and Western Europe the category of "identity" is understood more in terms of protecting groups vulnerable to discrimination, in Eastern Europe "identity" is associated rather with religious and national groups. Collision of various confessional and ethnic projects here in the past became the basis for the emergence of architectural manifestations designed to fix in the space the identity of this kind. Until now, all these manifestations were perceived equally as heritage, the heritage characteristics of which included only chronological and stylistic data. Aspects of identity and the meanings associated with it were not mentioned.

Eastern Europe, with its kaleidoscope of identities, is a specific area where this kind of expanded interpretation of the heritage category has great prospects and a wide range of development. The diversity of identities of national groups that emerged in the nineteenth century and the search for their architectural manifestation is seen in the example of comparing the implementation of Ukrainian, Polish and Russian narratives, which became the source of numerous experiments with architectural form.

\section{Results and Discussion}

The issue of national identity in itself has an extensive literature and goes beyond the scope of this article. In our context, it is important that during the transition from the feudal to the modern paradigm, emerged new groups, which received the conditional name of "nations", or "political nations". Through education and communication tools, during the XIX-th century, they took the form of political communities united by name, territory, historical narratives, and a number of other factors (Smit E. 1994). Since culture and art played an important role in uniting national identities, architecture faced the task of forming a stylistic series associated with a particular national narrative and bringing it into space, fixing it for a particular national group. The trends and tendencies that emerged in this regard became the object of theoretical reflection, especially in the postmodern era, when the fundamental principles of the New Age were critically rethought.

Among the works devoted to this topic is Lawrence Vale's monograph "Architecture, Power and National Identity", published in 1992 (Vale L., 1992) and later republished. The author focuses on the architecture of the capitals of major powers and historical cultural centres, tracing the relationship between government institutions and the symbolism of urban space, which was closely associated with them. It is important that Vale traces certain longevity of modern identities with the feudal - a kind of multi-layer of ideas and practice of metaphors and signs, which were involved by constructors of the new national groups.

An important work on the study of the relationship between modern identities and architecture was the monograph by Bohdan Cherkes "National Identity in the Architecture of the City" (Cherkes B., 2008). The author considers examples of several, primarily Eastern European cities, whose central parts have become a medium of manifestation of identity symbolism. The transformation of the concept of identity in the postmodern era is demonstrated by Kim Dovey's work "Places of formation: urbanism, architecture, identity, power" (Dovey K., 2009). These and other works laid the foundations for understanding the significance of the category of identity for the development of XIX-XX centuries architecture, including in a context that is close to the subject of this article.

The material elaborated by the above-mentioned authors has, to a large extent, an urban character and considers the ensemble complexes of cities, mostly their central, representative parts. In connection with this, the logical development of this topic is the analysis of morphological data itself, applied stylistics and the ways in which the visual demonstration of the presence of some newly emerged identity was achieved. 
Duringthe XIXth century in Eastern Europe took place the processes of mastering new political models, which were formed in the West as a result of the French Revolution. The feudal system of establishing and legitimization of power through "divine law" gave way to modern ideas about the people as a basic political category, the source of power and the legitimacy of its authority ("le principe des nationalites"). As a result, the process of forming new collectives began, which received the definition of "political nations". Peoples who were ruled by certain feudal began to govern themselves, and this required intensive work to reform them into collectives of new quality. In this context, it has become important to create national narratives - a set of facts and evidence about some group, primarily on the basis of memories and recollection of the past. These testimonies gave the newly created national collectives a sense of their own identity, place in history and the world (sometimes messianic). Although the narratives tried to be based on historical facts, they focused primarily on emotions and feelings.

In Eastern Europe traditions and conceptualism of democracy were weak due to the special way taken by feudalism in this region, becoming here a kind of form of slavery (Adzhemohlu D., Robinson Dzh. 2016). As a result, strong feudal elites, without much pressure from other social classes, had the opportunity to create their own modern identity of their subjects, or to take an active part in the creation of new collectives.

To the greatest extent, this process was inherent to the Russian Empire, where during the reign of Nicholas I started a concept of "Russian nationality". Having the state status and support of the empire's bureaucracy this concept has received significant materialization in various forms of culture, including architecture. To understand the project language, which arose as a result of the development of the concept of "Russian nationality", it is necessary to consider the main features that distinguish it from others and the ideological structure of this narrative.

After the Napoleonic Wars, the ideas of republicanism and constitutionalism began to spread among some of the Russian nobility. In December 1825, they initiated a failed uprising that forced the new Emperor Nicholas I to consider anti-monarchist and modernist movements. The following year, the Censorship Charter was amended banned now historical works that were not in favour of the monarchical type of government, banned the works of French Enlightenment and a positive assessment of any people's protests (Hrynchenko N., 2001). As a representative of the German dynasty, guided by the European example, Nicholas, however, understood the need to respond to nation-building processes. A detailed strategy for preserving the autocracy under the new conditions was entrusted to the President of the Imperial Academy of Sciences, Count Sergei Uvarov, who received the post of Minister of Education. As a result of the activities of Uvarov and a number of others, the concept of Russian "nationality" was developed, which in fact became the opposite of the European "nation" and "the principe des nationalites". Based on the historical works of Nikolai Karamzin, the Russian nationality was conceptualized not as an ethnic group but as a community "united by boundless devotion to its rulers", thus differing from Western peoples "corrupted by the philosophy of the Enlightenment" (Zoryn A., 1996). On the ground of such considerations, arose a well-known triad - "orthodoxy, autocracy, nationality", in which nationality was understood primarily as monarchical lower social groups, whose habit to autocratic rule became a new stronghold of Russian absolutism. For the historical substantiation of such a "nation", were used an episode of the so-called "vocation of the Varangians", when the Slavs of future Russia called for a Scandinavian dynasty to rule, complaining about the lack of order within them. This chronicle was favourably consonant with the then situation of the rule of the German dynasty, which thus received the support of the validity of the autocratic power of foreigners over the Russian people.

Such a concept required indoctrination into the mass consciousness with the expectation that the general public would independently support it. A combination of education and pathos was a way to achieve this goal. The Russian people should be proud of the autocratic form of rule, and the lack of political rights should be seen as an advantage. A picture of a happy and harmonious world based on the triad of "Orthodoxy, autocracy, nationality" was to appear. During the reign of Alexander III 
(1881-1894) an aesthetic system was developed, which primarily affected the architecture. If within the reign of Nicholas I, the spontaneous desire of the Russian people to obey the tsar was associated with the historical episode of "vocation of the Varangians", now more attention is paid to the events of the early seventeenth century, when the Romanov dynasty was called to power after the expulsion of Poles from Moscow. Having won a victory over the foreigners, the Moscow people did not want to rule themselves, or even limit the rights of the monarch, but set up an autocrat who had full power over them. Thus, the kingdom of the last Rurikids of the XVI-XVII centuries in Great Russia (Zalesye), began to be imagined as a kind of Ideal Homeland when the people lived happily and harmoniously under the rule of the tsar.

These considerations formed the framework for the architectural style, which was based on the representative construction of Moscow Rus' before its Europeanization by Peter I. The starting examples were such buildings as St. Basil's Cathedral, the Kremlin, Kolomenskoye and others. The first markers of a new direction were the Church of Christ the Savior in Moscow (1839-1883) and the Church of the Savior on Spilled Blood in St. Petersburg (1883-1907).

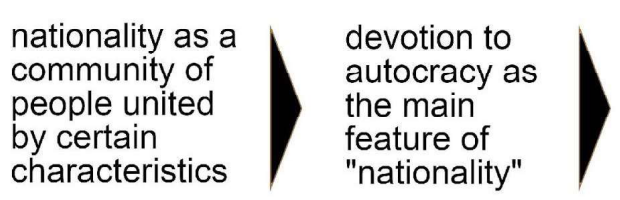

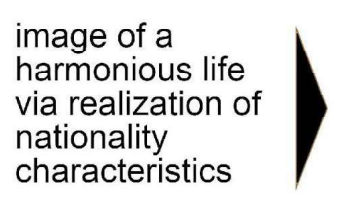

Fig. 1.

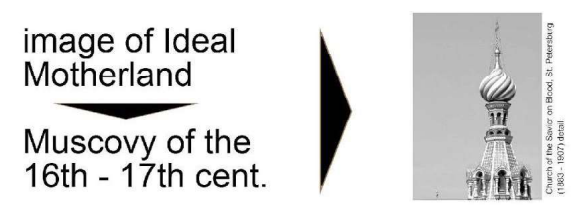

Thus, we can say that the objects of historicism, the style which emerged in the Russian Empire in the mid-nineteenth century, expressed the identity of the subject nation, formed for the duration of the autocratic monarchy and opposed to the modern nation concept. This kind of architecture marked the pathos of some Ideal Homeland from XVI-XVII centuries Muscovy (Fig. 1).

A special feature of the Polish nation-building was that this process took place in the absence of a full-fledged state of its own and the appropriate mechanisms that it could provide. In the XIXth century, the Polish ethnic area was divided between the German, Russian and Austrian empires, which differently ensured the religious, linguistic, and cultural rights of the Polish population. The matter of conceptualizing the modern nation began in part in the last years of the Polish-Lithuanian Commonwealth, and is connected with the adoption of the so-called "Constitution of 3 May". The document did not contain any truly revolutionary changes, such as those that took place at the same time in France (Skavronskyi P., 2020), but became a kind of legend about the unfulfilled nation-building for those generations who had to live in a period of statelessness. The creation of the Polish modern nation is characterized by several features that influenced the final result. In the era of Romanticism, with its idealization of the past, the plots of "old Poland" gradually lost their objectivity and were painted in positive and pathetic tones, which contributed to its rapid transformation into the Ideal Homeland. The search for modern conceptualization began to revolve around her image. This was facilitated by the unique political system of the First Rzeczpospolita, based on "noble democracy" and the concept of "Sarmatian noble nation" with an elected monarch and a noble parliament (Seim), which were perceived as very own version of modernity. The medium of the Polish nobility was probably influenced by Hungarian practice of contractual relations between the nobles and the king (Frankiv R., 2019) and was fare from full-fledged republican traditions. In the XVIth century, the humanist S. Orzechowski stated with admiration that in Poland "royal freedom" was available to every nobleman, who were all equal to each other, regardless of wealth (Orzechowski S. 1919). However, such proto-modern features were characteristic only of a small privileged class. The largest social group in the country - the peasants were deprived of any rights and were in the position of slaves. The romanticization of the XVIth and XVIIth 
centuries thus led to contradictory results; on the one hand, the noble nation and its republican traditions were the basis for the creation of its modernism, on the other hand, division of society into two unequal groups - the upper privileged class of "sarmatians" and the lower lawless "hams", did not allow to consider this modernism as real. The proposal of the Polish Romantics to build a new nation as a process of inclusion of "hams" in the number of "sarmatians" constantly encountered inconsistencies with the realities of the Ideal Homeland of the XVI-XVII centuries, a mandatory element of which was the opposition of the higher race to lower groups.

Under the conditions of divisions between the various states, the Roman Catholic Church was an institution that continued to unite the former body of the Polish-Lithuanian Commonwealth. Its structures, sceptical of the processes of modernization and secularization, thus got a chance to form a national narrative in their favour. In this regard, the elements of the Renaissance and Baroque, which symbolized the XVI-XVII centuries, gradually added the aesthetics of the Middle Ages as a period of the Ideal Homeland of Catholicism itself - with images of typical for Poland brick gothic. This kind of style successfully combined the colour combination of red brick and white stone as a paraphrase of the colours of the white and red national flag, but in the sense of historical symbolism, appealed only to the memory of the Polish ethnic lands on the Vistula without foundation in Rus` and Lithuania, which in the Gothic era professed Orthodoxy and paganism, respectively.

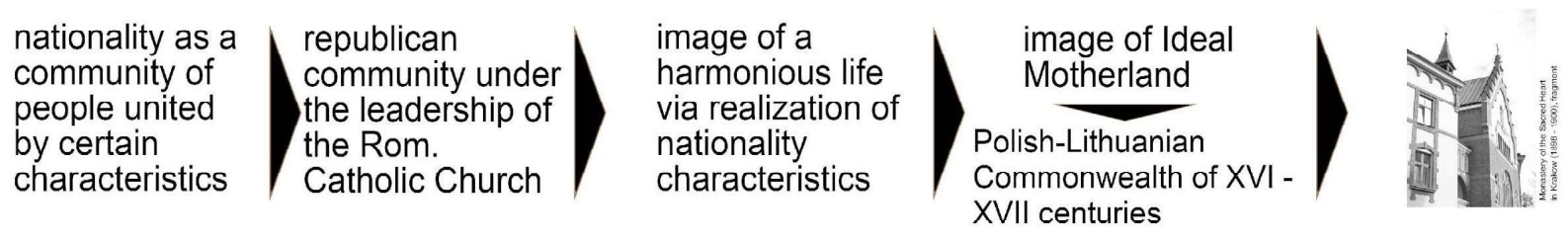

Fig. 2.

Thus, we can say that the narrative of the Polish modern nation is conceptualized as a community based on the traditions of aristocratic republicanism of the Ideal Homeland, but under the authority and control of the Roman Catholic hierarchy. In architectural language, this narrative was expressed in two ways, a combination of Renaissance elements (attics, pilasters etc.) and red-brick Gothic with elements of stone masonry (Fig. 2). An example of such a style can be some works of Felix Ksenzharsky, such as the chapel of St. Bronislawa (1856-1860) and the building of Collegium Novum (1883-1887). An interesting example of the combination of two language systems - representatives of modern Polish identity can be the monastery of the Sisters of the Hearts, designed by architect Vaclav Kachmarsky (1896-1900). All buildings are in Krakow.

The conceptualization of the Ukrainian modern nation took place in even more difficult conditions of stateless than the Polish one. If the Russian national identity was formed at the initiative and support of the state, and the Polish - well-secured in rights Roman Catholic Church and the feudal corporation, the Ukrainian did not have any of these factors. In the Russian Empire, where from the first half of the nineteenth century was banned the promotion of republican ideas and any criticism of monarchism, in the second half of the same century, were introduced a ban on the Ukrainian language. In the Austrian Empire, the curial system of elections and the establishment of foreign minorities governing in territories with a Rusyns demographic majority also hindered the development of modern nation-building. Nevertheless, it is likely that these factors were the reasons for the relative success of Ukrainian identity, which is clearly seen in the example of Austrian-ruled Galicia, where the ethnonym "Ukrainian" was previously used mainly to the inhabitants of the Dnipro lands.

Comparatively, Russian and Polish national projects supported by state and clerical institutions, the relative success of the Ukrainian one can be explained by its pure modernity. As of the beginning of the 
XIXth century, the Little Rus'(Ukrainian) lands were part of the Russian Empire, which was perceived as a monarchy of the Orthodox Tsar, equally close to the Great, Little, and Bela Russians. Thus, at the time of the start of nation-building processes in Europe, the chances of creating a single political nation of all three ethnic groups were quite high. However, the state program of Nicholas I to form a "Russian nationality" as a community of loyal subjects of the autocratic tsar, blocked the natural nation-building historically related to Rus` ethnic groups of the empire. This process, however, was not stopped at all and found its expression in the conceptualism of the Ukrainian modern nation. The pathos of romanticism at that time was used to actualize the experience of Zaporizhzhia (Cossack) democracy of the XVII-XVIIIth centuries. In fact, promoters of the Ukrainian idea contrasted it with the official "Russian nationality". If the "Russian nationality" was seen as a community characterized by voluntary submission to the autocratic power, the Ukrainian nation acted as a self-government community that existed without the help of the monarch or feudal lords.

Important monument to the conceptualization of the Ukrainian modern nation is the so-called "Book of the Genesis of the Ukrainian people", which arose among the underground Cyril and Methodius Brotherhood in Kyiv. In it, Ukraine is seen as a source of freedom and equality in Eastern Europe, from which originates the Polish constitutionalism of the XVIIIth century and the Russian Decembrist movement. Zaporizhzhya democracy, after the uprising of Bohdan Khmelnytsky, became the political system of a new state - the Hetmanate (wider Ukraine). Because the Book of Genesis is written in the form of a sacred text, the values of radical egalitarianism and personal freedom without division into ruling and subjugated classes, interpreted in a religious paradigm. The natural state of man is to obey only the Christian God, who acts as a good father and serves his creations, not dominate over them. If in the Russian project the people were seen as a stronghold of the autocracy, in the Ukrainian one they became its main opponent (Zaionchkovskyi P. 1959).

In this regard, the materialization of the Ukrainian political concept in architecture was seen as an appeal to the Ideal Homeland - a Cossack country on the Dnieper, and in a broader sense, to folk-building, because the people were perceived as the main bearer of memory about lost but not forgotten perfect society (Krychevskyi, V., 1914). The visualization of the national narrative, therefore, received two potential directions: one of them - the reproduction of a regional version of Baroque architecture of the XVII-VIII centuries, the second - work with the folk architecture of about the same period. The first tended to decorativism and sensual pathos, the second to monumentalism and abstract geometry. In practice, in experiments with the expression of national identity by means of architecture, these two tendencies were often mixed, which was characteristic also in original samples of the XVII-XVIII centuries (Fig. 3).
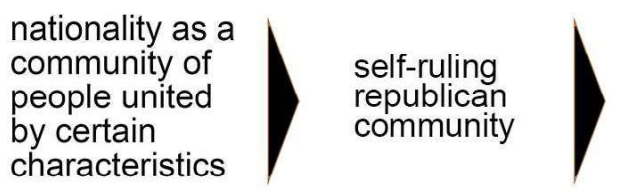

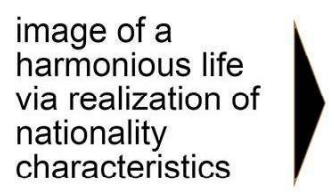

Fig. 3.
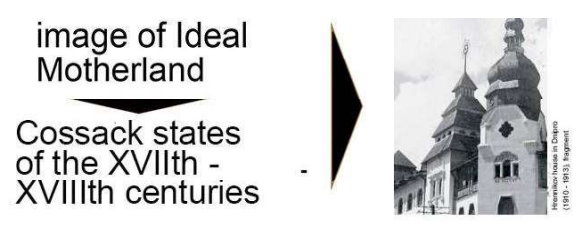

As can be seen from the analysis above, the nationally determined historicism of the XIX early XX centuries cannot be considered only as the introduction of elements of ethnic culture and national memory into architecture. These elements are vocabulary that conveys a certain view of the social system and the place of man in it. Although the architectural materializations of the Ukrainian, Polish and Russian national narratives discussed here operate on different decorative materials and can be visually easily distinguished, the difference between them is not exhaustive. 
All three "national styles" are the representations of different reactions to modernity's proposal to say goodbye to feudalism. In some cases it is negative, and in others it is positive. Such features of nationally determined historicism remain outside the cultural studies and institutional definition of these objects, are absent in media and scientific interpretation, as well as in the heritage certification of those buildings when its value is recognized at some state level.

\section{Conclusions}

In the context of the constant expansion and diversification of the category of architectural heritage, the question arises about a new understanding of the "value" concept of the building. In this regard, was outlined the problem of potential devaluation of the very concept of "value" and the need to formulate new criteria for the gradation of heritage. One of such criteria is proposed to be the identity that reflects a particular architectural object.

There were reviewed some examples of ideological conceptualization of three modern national identities: Ukrainian, Polish and Russian and the image of their Ideal Homeland, which became the source of an architectural plot for each of them. It is determined that each of these images has its version of the response to modernity, from its full acceptance to rejection.

The ideological program of a nationally determined historicism and its views on modernity, as the article shows, may be different. Just as different are the views of these programs on such categories as human rights, the level of freedom and access to progress opportunities. In this regard, it is proposed to include data on the appropriate ideological positioning of a nationally determined historicism in the structure of value description of architectural objects of their certification in the case of acquiring the status of architectural monuments and historical heritage.

\section{References}

Dovey K. 2009. Becoming Places: Urbanism / Architecture / Identity / Power, London, Routledge.

Jokilehto J. 2008. The idea of conservation: An overview. In Conservation and Preservation: Interactions between Theory and Practice: In Memoriam Alois Riegl (1858-1905): Proceedings of the International Conference of the ICOMOS International Scientific Committee for the Theory and the Philosophy of Conservation; Polistampa : Vienna. Austria. P. 1000-1015.

Lamprakos M. 2014. Riegls "modern cult of monuments" and the problem of value.

Chang. Time, r. 418-435.

Orzechowski S. 1919. Polskie dialogi polityczne. Biblioteka pisarzy Polskih. Krakow. S. 231

Vale L. 1992. Architecture, Power, and National Identity, New Haven Yale University Press.

Adzhemohlu D., Robinson Dzh. 2016. Why Nations Fail; The Origins of Power, Prosperity, and Poverty. Kyiv : Nash format. S. 105.

Hrynchenko N. 2001. History of censorship institutions in Russia in the first half of the XIX century. Tsenzura v Rossyy. Ystoryia y sovremennost. Sb. nauch. tr. No. 1. S.- Petersburg. S. 15-46.

Zaionchkovskyi P. 1959. Kyryllo-Mefodyevskoe obshchestvo. M. S. 149-159.

Zoryn A. 1996. Ideology of "pravoslavyia-samoderzhavyia-narodnost": reconstruction experience, Moscow : Novoe lyteraturnoe obozrenye, No. 26. Moscow, NLO. S. 86-87, 92-101.

Krychevskyi, V. 1914. Understanding of Ukrainian style. Siaivo Ch. 3. Kyiv. S. 89-91.

Smit E. 1994. National identity. Kyiv. Osnovy.

Skavronskyi P. 2020. 3 maia 1791. The constitution that became a revolution. [online] Novaia Polsha. [Available at:] $<$ https://www.novayapolsha.pl/article/3-maya-1791-konstituciya-stavshaya-revolyuciei/> [Accessed date: 15 August 2020].

Frankiv R. 2019. The people and power in Halych as a example of the "Byzantine Republic". Halych : Collection of scientific works. No. 4. S. 82-94.

Cherkes B. 2008. National identity in architecture of the city, Lviv : Vydavnytstvo Natsionalnoho universytetu "Lvivska politekhnika". 


\section{Роман Франків}

Канд. арх., дои. кафедри дизайну та основ архітектури

Інституту архітектури та дизайну

Начіональний університет “Львівська політехніка”, Львів

e-mail: romanfrankiv@gmail.com

orcid: 0000-0003-1100-0930

\section{ІДЕОЛОГІЧНІ АСПЕКТИ АРХІТЕКТУРИ НАЦІОНАЛЬНО ДЕТЕРМІНОВАНОГО ІСТОРИЗМУ НА ПРИКЛАДІ УКРАЇНСЬКОГО, ПОЛЬСЬКОГО ТА РОСІЙСЬКОГО НАРАТИВІВ}

Анотація. Стаття присвячена проблематиці тлумачення об'єктів архітектурної спадщини, в контексті постійного збільшення їх кількості та розширення їх типологічного спектру, що веде до загрози релятивізації поняття "иінності"; в зв'язку із иим, виникає необхідність розиирення формулювання категорії цінності тих чи інших об'єктів спадщини. Одним із досі не задіяних ресурсів, у иьому контексті, може вважатись поняття ідентичності, розуміння якої потребує теоретичної кваліфікачії.

В рамках иих пошуків, у статті розглядаються ідеологічні аспекти архітектури національно детермінованого історизму ХІХ століття. На прикладі украӥнського, польського та російського наративів простежено роль пафосу Ідеальної Батьківщини та конструювання психологічної прив'язаності до середовища тої чи іншої новопосталої нації. Здійснено аналіз концептуальних засад, які лягли в основу творення всіх трьох ідентичностей та були пов'язані із специфікою зміни феодальної парадигми та модерну у регіоні Східної Свропи. Запропоновано принцип оціночної диференціації цього виду спадщини залежно від властивих кожній з них символічних ідеалів, трансльованих тою чи іншою конструкиією національної ідентичності.

Ключові слова: історизм, начія, сучасність, наратив, ідентичність, модерна доба, феодалізм. 